\title{
Jbatik Software As An Applications In Batik Kudus Craft Industry
}

\author{
Nafi' InayatiZahro ${ }^{1}$, Sutono $^{2}$, Noor Latifah ${ }^{3}$ \\ \{nafi'.inayati@umk.ac.id ${ }^{1}$, sutono@umk.ac.id ${ }^{2}$,noor.latifah@umk.ac.id ${ }^{3}$ \} \\ University of Muria Kudus, Gondang Manis PO BOX 53 Bae Kudus, Indonesia ${ }^{123}$
}

\begin{abstract}
Kudus is a small town with a variety of diversity in its community. Batik Kudus is an industry that raised the culture of "Local Wisdom", from the side of the motifs raised local culture and folklore Kudus into a uniqueness of its own compared to other batik. Its also an export commodity to increasing foreign exchange, introduces Indonesian culture to the world. This study employs fractal algorithms to generate and transform original Kudus ornaments into architectural design. The interpretation and generation of this ornaments by fractal method uses L-system based software called jBatik. This software approach of preserving local ornaments using three stages: understanding the local ornament geometry function, interpreting and generating new ornament using fractal method, exploring the possible iterations of patterns based on fractal algorithms. Its also employs e filing application software to make it easier for SMEs to calculate and report tax.
\end{abstract}

Keywords: design, software, tax, production, marketing.

\section{Introduction}

Kudus City is a small town with a wide variety of diversity in its community. Starting from religion, work, commerce, to culture. In the city of Kudus, there are also 2 Sunan from Walisongo who spread Islam in the ancient island of Java. Sunan Kudus himself left a teaching "Gusjigang". Gusjigang is an acronym of "bagus, ngaji, dagang". Gus means bagus, ji means ngaji, gang means dagang. In Gusjigang is an acronym of "bagus, ngaji, dagang". Gus means bagus, ji means ngaji, gang means dagang. In the sense of good morals, diligent study, and clever trade.Gusjigang itself has been firmly attached to the life of the Kudus community.

Just like batik in other coastal areas such as Pekalongan batik, Jepara batik, Pati batik or Lasem batik, Kudus batik also has a bright color with unique motifs that are so typical. One thing that distinguishes Kudus batik with other batik is the cultural acculturation between Chinese culture, pribumi, with elements of Islam. Because Kudus is the origin of two WaliSongo spreaders of Islam in the Land of Java, namely Sunan Kudus and SunanMuria, so there are elements in the Kudus batik motif. The Islamic accent in Kudus batik is present in motifs such as the Kudus Tower, Islamic calligraphy, and so on. However, Kudus batik motif also contains local wisdom of Kudus society. This can be seen from the emergence of motives such as kapal kandas, parijotho, pakis haji, gebyok, bulusan and isen-isenberaskecer.

In addition, another characteristic of Kudus batik is the color selection. Kudus Batik is usually dominant with traditional color of sogan or brown color or indigo blue. Sogan color is

ICCSET 2018, October 25-26, Kudus, Indonesia

Copyright (C) 2018 EAI

DOI 10.4108/eai.24-10-2018.2280622 
actually visible in batik-batik from Jogja and Solo. However, the presence of sogan color on Kudus batik was hinted as acculturation and influence obtained from other types of batik.

Formerly the design of batik made by using a regular pencil and takes days to make it. Along with the development of current technology of batik design can be done by using the application commuter program one of them with $\mathrm{jBatik}$ software.

Among other cultural heritages in Indonesia, Kudus ornaments is one of the local legacy that could be preserved and revitalized in order to foster creatives ideas for contemporary architectural design based on locality [1]. The fractal method is one of the possible approach to understand and to reproduce the patterns within the Kudus ornaments. This method can be utilized to transform original basic pattern into a new and innovative patterns without losing its identity [2], [3].

\section{Implementation And Methods}

Implementation of Export Product Development Program (PPPE) activities for the first year is implemented starting in February 2018 on two partner SMEs namely SMEs Alfa Shoofa and SME Muria Batik. The method used in implementing PPPE is the transfer of appropriate technology to both Partner SMEs, namely application training and jBatik software implementation to design batik pattern using computer technology as well as facilitation and training of e-filing in order to report taxation properly and correctly. The other method are market expansion, not only the local market but also penetrate the international market as well.

The jBatik software is improve batik design using computer with the Kudus heritage cultural ornaments. The ornaments of Kudus is highly influenced by Kudus culture such as Menara Kudus, Jenang Kudus, Lentog Tanjung, Kretek, tobbaco leaf, etc. Most ornaments being used for decorations are Kudus culture patterns and geometrics since the representations of figures is prohibited Kudus heritage culture.

The preservatin of Kudus ornament in this paper conducted using three stages as follows: 1. Understanding its original geometrics iterations in mathematic functions. 2. Generating artificial pattern using fractal method with rules derived from original ornament. 3. Exploring the possible iterations of patterns based on fractal algorithms.

\section{Results And Discussion}

Kudus batik PPPE activity is intended to improve and develop batik craft industry in the city of Kudus through the application of technology so that batik craft industry able to compete in global level, including the results of activities that have been implemented are:

\subsection{Training and application software jBatik on batik craft industry Kudus}

Long ago, when the batik craftsmen take days to weeks to make it. In fact, to meet market needs, SMEs Batik is required to be able to produce quickly. Jbatik is a software for creating batik motif design that use fractal formulas . Where fractal is a branch mathematical sciences 
that learn about repetitions and similarities that are usually produced in a wayrepeat a composition. There are two types of Jbatik namely, the first jBatik Pro that can help make modular motifs in two dimensions and three dimensions, also arrange a compositionmotive. Secondly, jBatik Basic is software that can only help those who manage it composition of motives alone. With jBatik design software, the process of making batik patterns can be done by mapping the patterns of batik mathematically to be translated in the form of pattern of digital batik pattern by jBatik software. Even with just one pattern when combined with other patterns in jBatik can produce new batik patterns. jBatik is a desktop software with parametric system to create batik patterns and other patterns. The $\mathbf{J}$ in JBatik is taken from the word "Java", because the software is developed on the Java platform. jBatik also won the Unesco 2008 Award of Excellence as "Stamp of Approval" which ensures their products are of the highest quality at international level and have great potential to enter the world market JBatik is desktop software with parametric system to create batik pattern and other patterns. Fractal pattern is generated by mathematical function within recursive and iterative process in a finite or infinite sequence.

The fractal patterns has four characteristics that exploited in this study namely :

1. Self similarity: a part of the fractal is identical to the entire fractal or the pattern of a smaller scale is identical to the bigger scale.

2. Self affinity: an anisotropic transformation whereas a part of the fractal is scaled by different amounts in the $x-, y-$ and zdimensions. [4], [5]

Various functions to make batik patterns with jBatik include:

a. One pattern for some new patterns. Software jBatik able to create a pattern can produce a variety of new patterns just by changing the parameters only.

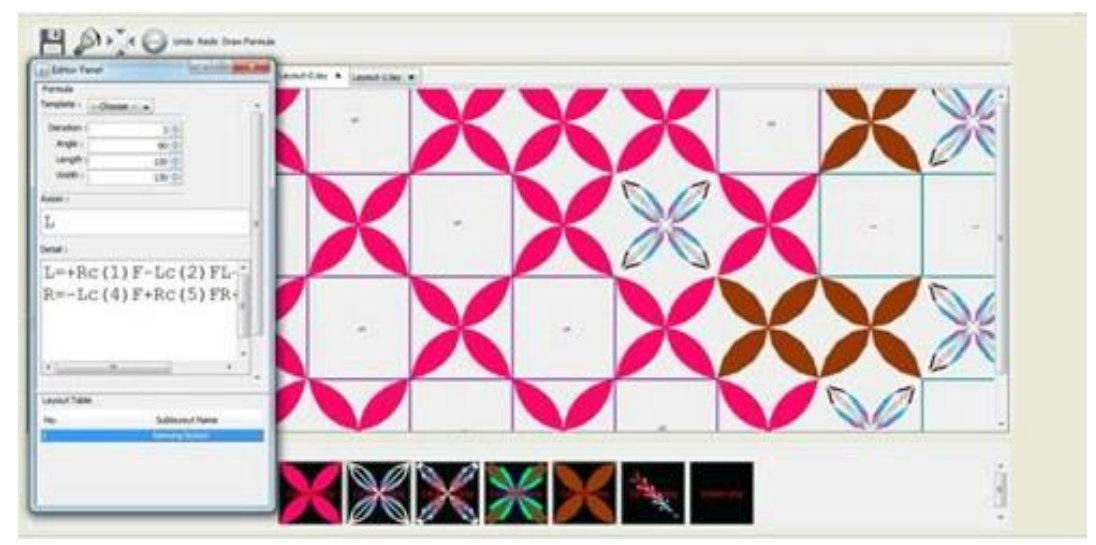

Fig. 1. Create a pattern can produce a variety of new patterns.

b. Draw Formula. This is one of the features available in jBatik by drawing a simple pattern, this jBatik software automatically creates formulas about patterns drawn and can also be edited. 


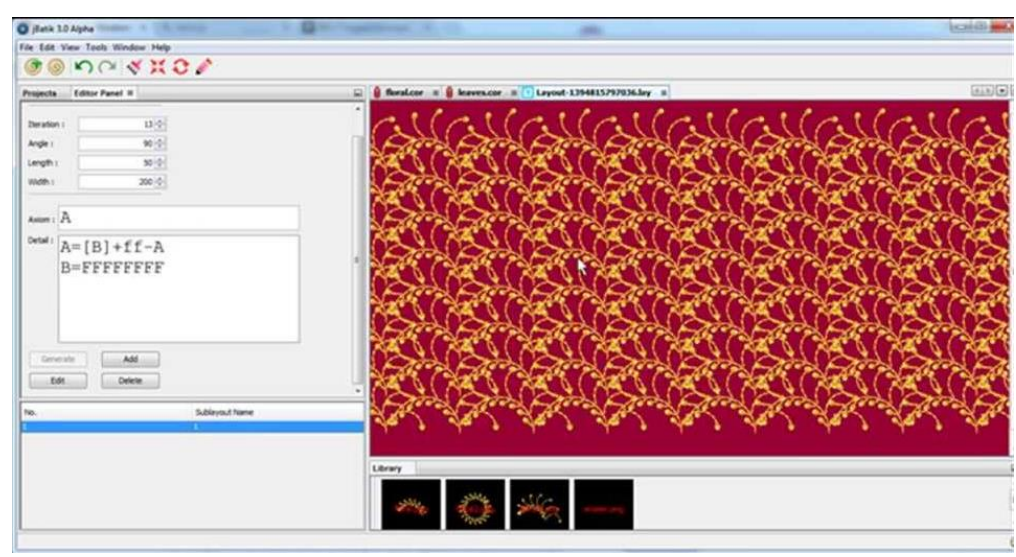

Fig. 2. Draw Formula.

c. 3D Patterns.jBatik able to produce patterns in the form of 3D batik with a view of the right, left, front and rear in accordance with the desired look.

d. Layout and edit. Like software for drawing or designing in general, jBatik also features layout and edit. Object pattern is taken from storage media then in layout with template layout on feature $\mathrm{jBatik}$. For pattern colors and pattern positions can be edited back as you wish through the edit feature.

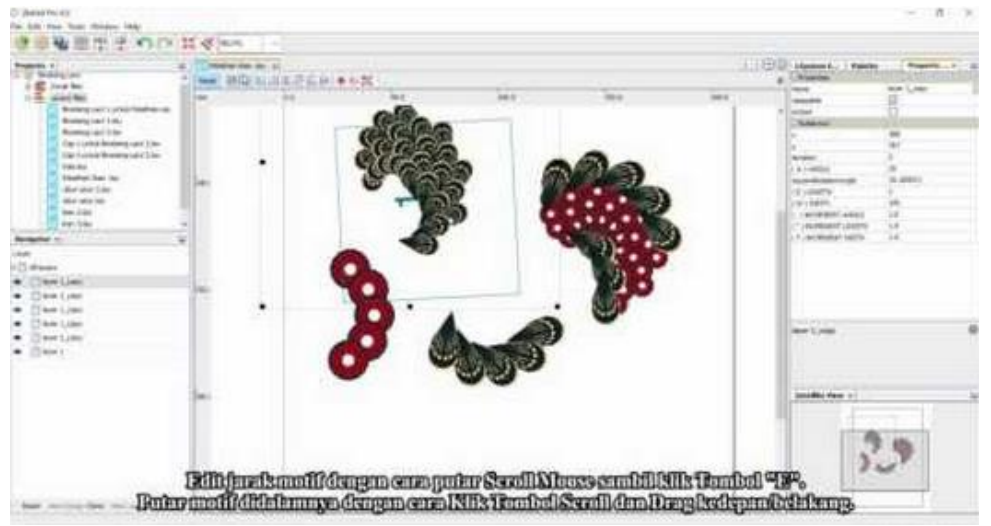

Fig. 3. Layout and Edit.

e. Import images from other storage media. Not only the patterns provided in jBatik software that can be used, but also can choose the desired pattern alternative by way of importing pattern in format.png then in layout using jBatik formula. 


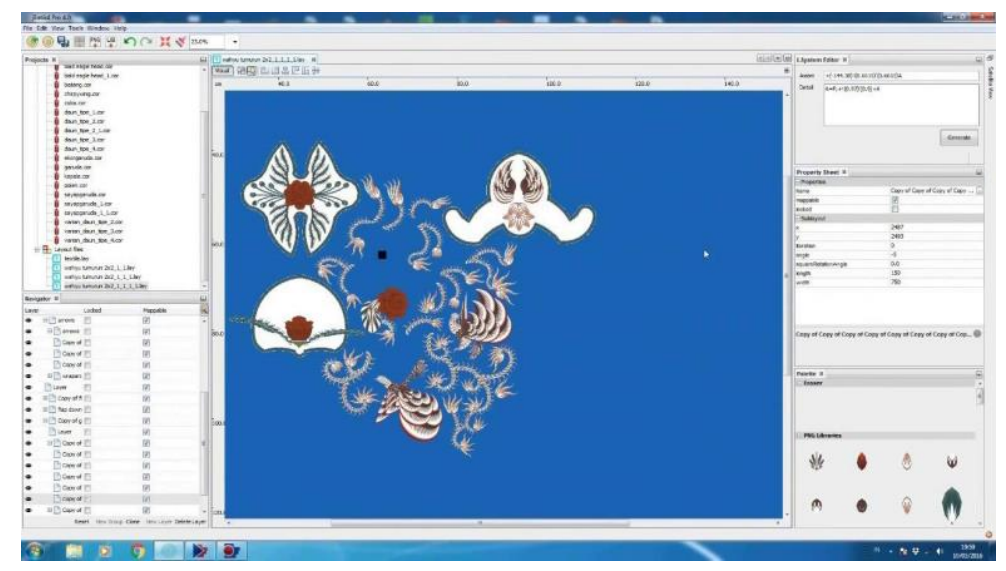

Fig. 4. Import images from storage media.

\subsection{Training and Assistance Filling E-filing taxation}

As entrepreneurs in SMEs Batik, tax becomes a compulsory contribution that must be paid by the government for the smooth development of the country itself, because the tax plays an important role and as the main source of state revenue. The tax reporting process itself is still considered to be a difficult and an obstacle for SME entrepreneurs, and is considered to be time consuming. But with the reporting of SPT On Line with E-filing, the entrepreneurs do not need far to come to the local tax office. E-filling is a way submission of SPT (Period and Year) or notification of extension of annual swhich is done in real time onlinethrough an Application Provider or Application Service Provider (ASP) [6]. The understanding of taxation owned by tax payers is affecting texpayers compliance level [7]. The higher it is level of understanding of taxpayers, than the easier it is for them to fullfill its tax obligations. But there are still taxpayers who haven't understand it not even understand yet totally related to regulations taxation [8].

But also this is still a constraint for the perpetrators of SMEs Batik because they still can not apply this application on line. With this e-filing filling training can improve the ability and knowledge in taxation. By using tax applications that are integrated with the SPT Online reporting system, such as the Online Tax e-filing application can also minimize the occurrence of tax calculation errors.

Generally e-Filing through the site Direktorat Jenderal Pajak (DJP), which address at www.pajak.go.id, is SPT reporting system uses internet facilities without going through other parties and without any fees, made by DJP to provide convenience for WP in the making and submission SPT report to DJP more easy, faster, and cheaper. With e-Filing, WP doesn't need to be waiting for a long queue at the location Dropbox or Tax Service Office (KPP). This is one new breakthrough reporting of SPT DJP rolled out to make WP getting easier and more comfortable inside carry out its tax responsibility [9].

The steps are as follows:To report the Company's Annual SPT, as well as SPT Masa, firstly prepare CSV SPT Annual Body on e-SPT or e-Form DJP Online, the following attachments required in 1 PDF file named the same as CSV file. 
1. Login / menu list E-filing Online tax then select menu "eFilling CSV"

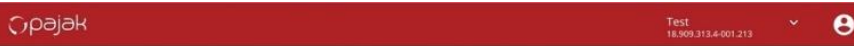

Apa yang ingin Anda lakukan sekarang?
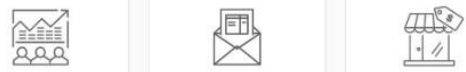

$\mathrm{PPh} 21$

e-Faktur \& PPN

PPh Final

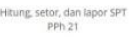

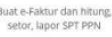
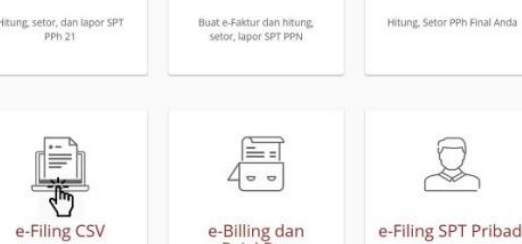

e-Billing dan
PajakPay

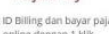

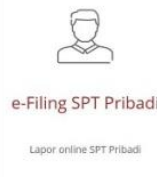

Fig. 5. .Login / menu list E-filing Online tax.

2. Upload the CSV and its Appendix

Click the "Upload" button to upload a CSV and PDF attachment if any. Make sure CSV and PDF file names have the same name

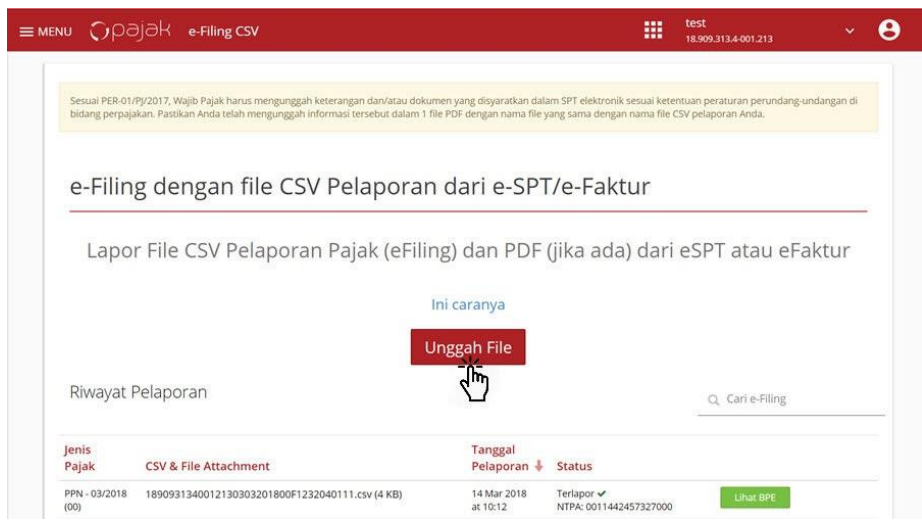

Fig. 6. Menu Upload the CSV and its Appendix.

3. Select the file on the local computer Select the agency's Annual SPT CSV file, the following PDF Attachment with the same name as the CSV file at the same time. Then click "Open" to upload it. 


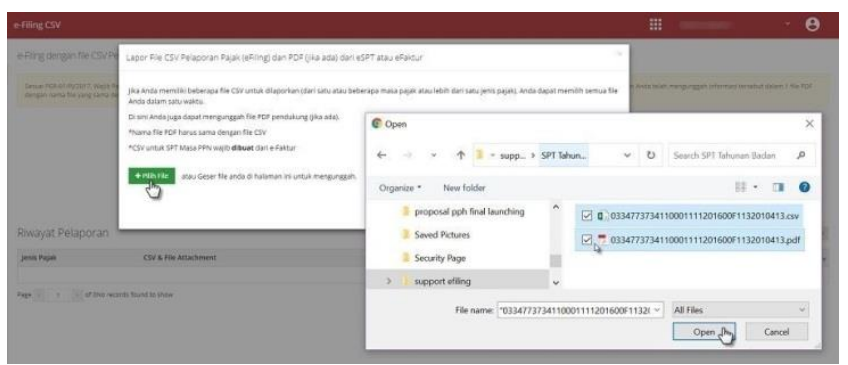

Fig. 7. Menu Select the file on the local computer.

4. Click the "Report" button

Click the "Report" button to report tax

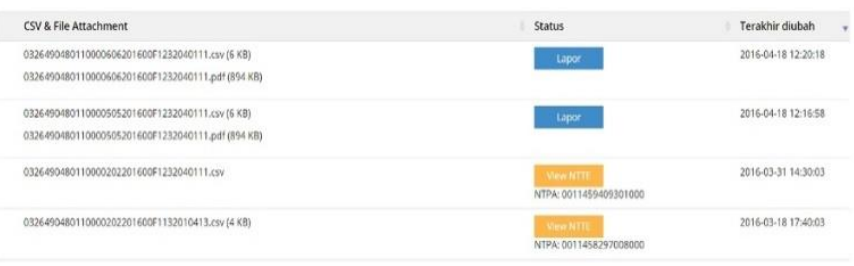

Fig. 8. Report Button.

\section{Receive Proof of Report}

Receive valid electronic reporting (Proof of electronic receipt / Electronic Receipt Number) from DGT. Click the "View CPE" button to download and print electronic receipt.

\subsection{Marketing Expansion}

About of expansion of marketing among others is done by improving and developing the budget through website. In addition, in order to increase sales turnover of products by following exhibitions at home and abroad, including in Malaysia following Exhibition Indonesia Creative Product Festival in Putra Word Trade Center Kuala Lumpur Malaysia, Muslim Fashion Festival, Civex Exhibition in Batam Riau, Exhibition at JCC Senayan, following the Indonesian Fashion Chamber, as well as through coverage on television and print media. In an effort to expand the market network, the PPPE team has also prepared brochures, business cards and product catalogs.

\section{Conclusion}

Based on the research that has been done, conclusions can be taken as follows: 
1. This Product Development Export Program of Batik Kudus has benefited SMEs partner in Kudus. This first year PPPE program focused on technology transfer, administration management improvement, and marketing. From the program activity of PPPE is developed jBatik software application to design batik pattern, so that yielded better pattern and faster time so that able to increase productivity of SME each partner, production capacity also increase, sales too, so its earnings increase also

2. The expansion of each SME market has also increased, getting customers from various regions, agencies, also export to various countries either directly or indirectly, including to Malaysia, Singapore, Brunei, and Korea. Expansion of marketing is also done by following the national and international expo events, through exhibitions in several cities including Jakarta, Semarang, Batam, Bali, also overseas expo in Kuala Lumpur Malaysia. In addition to establishing cooperation with the local government of Kudus regency, the Industry and trade office, the department of Cooperatives and SMEs, BUMN, also took the famous designers such as Denny Wirawan and Ivan Gunawan. The introduction of Kudus batik is also through mass media both print and television, through the coverage of TV stations, has been broadcast on MNC as well as metro TV, and Trans 7

3. The improvement of management aspects, financial management and administration has also been well implemented, with the implementation of sales system using computerization and recording financial and inventory with computer applications make the financial statements can be arranged well according to Financial Accounting standards, so it can be known profit and business costs, able to perform the tax calculation well and report on line through e-filing application.

\section{Acknowledgments}

With regard to the implementation of PPPE program of Kudus Batik Craft Industry in Kudus Regency of Central Java Province, we would like to extend our greatest thanks to:

1. Directorate of Research and Community Service Directorate General Strengthening Research and Development Ministry of Research, Technology and Higher Education for the funding provided so that PPPE program of Batik Kudus craft can run well.

2. Rector of Muria Kudus University with permission and direction given in the implementation of this program.

3. Chairman of LPPM Muria Kudus University for the direction and encouragement given during this and in the future.

4. Both partner SMEs are SMEs Alfa Shoofa and SME Muria Batik for cooperation and participation during this and in the future.

\section{References}

[1] a. Indraprastha, z. Sahputra, and a. Suharjono, "preserving local ornament through algorithm," j. Comput. Sci. Inf., vol. 6, no. 2, pp. 52-58, 2013.

[2] k. Elam, geometry of design: studies in proportion and composition. New york: princeton architectural press, 2001.

[3] m. Ghyka, the geometry of art and life. New york: dover publication, inc., 1977.

[4] g. Stiny and j. Gips, algorithmic aesthetics: computer models for criticism and design in the arts. Berkeley and los angeles, london: university of california press, 1978. 
[5] j. Burry and m. Burry, the new mathematics of architecture. United kingdom: british library, 2010. [6] w. Agustiningsih and isroah, "Pengaruh Penerapan E-Filing, Tingkat Pemahaman Perpajakan Dan Kesadaran Wajib Pajak Terhadap Kepatuhan Wajib Pajak Di Kpp Pratama Yogyakarta,” J. Nominal, vol. V, no. 4, pp. 107-122, 2016.

[7] S. Nurmantu, Pengantar Perpajakan. Jakarta: Yayasan Obor Indonesia, 2005.

[8] S. Ernawati and M. Wijaya, "Pengaruh Pemahaman akuntansi Pajak Terhadap Kepatuhan Wajib Pajak Badan Usaha Di Bidang Perdagangan Di Kantor Pelayanan Pajak Pratama Banjarmasin,” J. SPRED, vol. 1, no. 1, pp. 74-86, 2011.

[9] E. D. JAYANTI, "Pengaruh Penerapan Sistem E-Filing, Pemahaman Perpajakan Dan Kesadaran Wajib Pajak Terhadap Kepatuhan Wajib Pajak,” STIE PERBANAS SURABAYA, 2017. 